\title{
Different coordination abilities of 1,7- and 4,7-phenanthroline in the reactions with copper(II) salts: Structural characterization and biological evaluation of the reaction products
}

\author{
Nevena Lj. Stevanović ${ }^{\mathrm{a}, 1}$, Tina P. Andrejević ${ }^{\mathrm{a}, 1}$, Aurélien Crochet $^{\mathrm{b}}$, Tatjana Ilic-Tomic ${ }^{\mathrm{c}}$, Nenad S. Drašković ${ }^{\mathrm{d}}$, \\ Jasmina Nikodinovic-Runic ${ }^{c}$, Katharina M. Fromm ${ }^{\mathrm{b}}$, Miloš I. Djuran ${ }^{\mathrm{e}}$, Biljana Đ. Glišić ${ }^{\mathrm{a}, *}$ \\ a University of Kragujevac, Faculty of Science, Department of Chemistry, R. Domanovića 12, 34000 Kragujevac, Serbia \\ ${ }^{\mathrm{b}}$ Department of Chemistry, University of Fribourg, Chemin du Musée 9, CH-1700 Fribourg, Switzerland \\ ${ }^{\mathrm{C}}$ Institute of Molecular Genetics and Genetic Engineering, University of Belgrade, Vojvode Stepe 444a, 11000 Belgrade, Serbia \\ ${ }^{\mathrm{d}}$ University of Priština-Kosovska Mitrovica, Faculty of Agriculture, Kopaonička bb, 38228 Lešak, Serbia \\ e Serbian Academy of Sciences and Arts, Knez Mihailova 35, 11000 Belgrade, Serbia
}

Keywords:

Copper(II)

Phenanthroline

Structural characterization Antimicrobial activity

Cytotoxicity

\begin{abstract}
The reactions between equimolar amounts of $\mathrm{CuX}_{2}\left(\mathrm{X}=\mathrm{NO}_{3}^{-}\right.$and $\left.\mathrm{CF}_{3} \mathrm{SO}_{3}^{-}\right)$and two aromatic nitrogencontaining heterocycles differing in the position of nitrogen atoms, 1,7- and 4,7-phenanthroline (1,7and 4,7-phen), were performed in ethanol/methanol at room temperature. When $\mathrm{CuX}_{2}$ salts were mixed with 4,7-phen, two copper(II) complexes, $\left[\mathrm{Cu}\left(\mathrm{NO}_{3}\right)_{2}(4,7-\mathrm{Hphen})_{2}\right]\left(\mathrm{NO}_{3}\right)_{2}$ (1) and $\left[\mathrm{Cu}\left(\mathrm{CF}_{3} \mathrm{SO}_{3}\right)(4,7-\right.$ phen $\left.)_{2}\left(\mathrm{H}_{2} \mathrm{O}\right)_{2}\right] \mathrm{CF}_{3} \mathrm{SO}_{3}(\mathbf{2})$, were formed. On the other hand, in the reaction of $\mathrm{CuX}_{2}$ salts with 1,7-phen, only 1,7--HphenNO $\mathrm{N}_{3}(\mathbf{3 a} / \mathbf{b})$ and $1,7-\mathrm{HphenCF}_{3} \mathrm{SO}_{3}(\mathbf{4})$ were obtained as the final products. The obtained products 1-4 were characterized by spectroscopic and X-ray diffraction techniques. In the copper(II) complexes $\mathbf{1}$ and $\mathbf{2}$, the coordination geometry around the $\mathrm{Cu}(\mathrm{II})$ ion is distorted octahedral and square pyramidal, respectively. The antimicrobial potential of the copper(II) complexes $\mathbf{1}$ and $\mathbf{2}$ and corresponding compounds used for their synthesis were assessed against four different bacterial species and Candida albicans, displaying moderate growth inhibiting activity. The cytotoxic properties of the investigated complexes were also evaluated against the normal human lung fibroblast cell line (MRC-5) indicating moderate, yet more pronounced cytotoxicity than antimicrobial properties.
\end{abstract}

\section{Introduction}

Copper is an essential element for almost all aerobic organisms and is found in both animals and plants in different metalloenzymes, such as superoxide dismutase, cytochrome c oxidase, ceruloplasmin, tyrosinase and metallothioneins [1]. Under physiological conditions, copper exists in two redox states, cuprous $\left(\mathrm{Cu}^{+}\right)$and cupric $\left(\mathrm{Cu}^{2+}\right)$, coordinated to proteins, while free copper ions participate in the Fenton reaction leading to the formation of reactive oxygen species [2]. As a soft Lewis acid, the $\mathrm{Cu}(\mathrm{I})$ ion tends to interact with soft sulfur- and phosphorus-donor atoms mostly forming complexes of tetrahedral geometry, although complexes with nitrogen- and oxygen-donors are also reported [3]. The $\mathrm{Cu}$ (II) ion is an intermediate Lewis acid and commonly forms com-

\footnotetext{
* Corresponding author. Fax: +38134335040.

E-mail address: biljana.glisic@pmf.kg.ac.rs (B.Đ. Glišić).

${ }^{1}$ N.Lj.S. and T.P.A. contributed equally.
}

plexes with nitrogen- and oxygen-donors, whereby coordination numbers 4,5 and 6 are predominating. The ability of copper to cycle between two oxidation states determines its biological function as a cofactor in enzymes catalyzing different redox reactions, such as the oxidation of catechols, superoxide, ascorbate, as well as iron $[3,4]$. Consequently, copper-containing metalloenzymes support wide range of pharmacologically important processes including mitochondrial oxidative phosphorylation, neurotransmitter biosynthesis, antioxidant protection, pigment formation, central nervous system development, connective tissue formation, iron metabolism and copper transport [5-10].

Besides its essentiality, copper has been used as a potent antimicrobial agent for the treatment of wounds and sterilization of water throughout the history of civilization $[11,12]$. It was found that surfaces containing 55-70\% copper are efficient against several bacteria, such as Escherichia coli, Enterococcus faecalis, Staphylococcus aureus, against the fungus Candida albicans, as well as against influenza viruses and the human immunodeficiency 
virus (HIV) [13]. Between 2008 and 2011, the Environmental Protection Agency (EPA) registered more than 300 copper-based alloys as antimicrobial agents that are effective against the microorganisms responsible for the life-threatening infections, which was part of the initiative for the manufacture of antimicrobial copper-based surfaces in veterinary and healthcare settings [14]. There are different factors, which have an influence on the antimicrobial properties of copper: temperature and humidity, wet or dry application, concentration, type of contact and form of copper [12]. Due to the fact that simple inorganic salts of copper are usually toxic, a large number of copper(II) complexes have been synthesized and evaluated for their antimicrobial activities [15]. One of the advantages in the administration of copper in a form of a complex is the selective delivery of copper ions to the diseased tissues as well as the modification of pharmacokinetics and/or pharmacodynamics due to the ligands [15]. Various copper(II) complexes with different ligands showed considerable antibacterial and antifungal activities [16-21]. Very recently, five copper(II) complexes with aromatic nitrogen-containing heterocycles ( $N$-heterocycles), e.g. pyrimidine, pyrazine, quinazoline and phthalazine, were synthesized and evaluated for their activity against three clinically important pathogens, namely Pseudomonas aeruginosa, Staphylococcus aureus and Candida albicans [22]. The obtained results showed that none of the studied copper(II) complexes manifested significant growth inhibiting activity against the investigated strains. Nevertheless, these complexes were able to inhibit bacterial quorum sensing (QS) through the modulation of the level of signaling molecules that are part of QS system [22]. This finding was very important in view of the development of novel therapeutic agents that attenuate virulence rather than microbial growth, thus offering a lower risk of resistance development. A considerable effect has been put into designing copper complexes as anticancer agents as well, utilizing the fact that the altered metabolism of cancer cells induces a differential response towards endogenous metal ions in comparison to healthy cells [23].

Although 1,7-phenanthroline (1,7-phen) and 4,7-phenanthroline (4,7-phen) showed no significant biological activity, these $\mathrm{N}$ heterocycles were utilized for the synthesis of metal complexes showing remarkable biological features [24-26]. Silver(I) complexes with these ligands exhibited potent antifungal activity and a good toxicological profile in the zebrafish model [24,25], while mononuclear gold(III) complexes, $\left[\mathrm{AuCl}_{3}(1,7-\mathrm{phen})\right]$ and $\left[\mathrm{AuCl}_{3}(4,7-\right.$ phen $\left.)\right]$ had a markedly higher anti-angiogenic potential than that of clinically relevant drugs, auranofin and sunitinib [26]. Considering this, in the present study, we have decided to perform reactions between these two $\mathrm{N}$-heterocycles and $\mathrm{Cu}$ (II) ions. The reactions between $\mathrm{CuX}_{2}$ salts $\left(\mathrm{X}=\mathrm{NO}_{3}^{-}\right.$and $\left.\mathrm{CF}_{3} \mathrm{SO}_{3}^{-}\right)$and 4,7-phen lead to the formation of copper(II) complexes, $\left[\mathrm{Cu}\left(\mathrm{NO}_{3}\right)_{2}(4,7-\right.$ Hphen $\left.)_{2}\right]\left(\mathrm{NO}_{3}\right)_{2}(\mathbf{1})$ and $\left[\mathrm{Cu}\left(\mathrm{CF}_{3} \mathrm{SO}_{3}\right)(4,7-\text { phen })_{2}\left(\mathrm{H}_{2} \mathrm{O}\right)_{2}\right] \mathrm{CF}_{3} \mathrm{SO}_{3}(\mathbf{2})$. However, in the reactions of 1,7-phen with these two copper(II) salts, only 1,7-HphenNO $\mathrm{N}_{3}(\mathbf{3 a} / \mathbf{b})$ and $1,7-\mathrm{HphenCF}_{3} \mathrm{SO}_{3}(\mathbf{4})$ products were obtained. The final products of these reactions 1-4 were characterized by spectroscopy and X-ray crystallography. In vitro antimicrobial and cytotoxic properties of copper(II) complexes 1 and $\mathbf{2}$ were evaluated against a panel of microbial strains and healthy human lung fibroblast cell line (MRC-5).

\section{Experimental}

\subsection{Materials and methods}

The copper(II) salts $\left(\mathrm{Cu}\left(\mathrm{NO}_{3}\right)_{2} \cdot 3 \mathrm{H}_{2} \mathrm{O}\right.$ and $\left.\mathrm{Cu}\left(\mathrm{CF}_{3} \mathrm{SO}_{3}\right)_{2}\right), 1,7-$ phenanthroline (1,7-phen), 4,7-phenanthroline (4,7-phen), ethanol, methanol, acetonitrile, dimethyl sulfoxide (DMSO) and deuterated dimethyl sulfoxide (DMSO- $d_{6}$ ) were obtained from
Sigma-Aldrich. All chemicals were of reagent-grade quality or higher and used without further purification.

The elemental analyses of the obtained compounds 1-4 for carbon, hydrogen and nitrogen were performed by the Microanalytical Laboratory, Faculty of Chemistry, University of Belgrade. The IR spectra were recorded as $\mathrm{KBr}$ pellets on a Perkin Elmer Spectrum 100 spectrometer over the wavenumber range of $4000-450 \mathrm{~cm}^{-1}$. The UV-Vis spectra were recorded on a Shimadzu double-beam spectrophotometer after dissolving the corresponding compound in DMSO and after 24 and $48 \mathrm{~h}$ standing at room temperature over the wavelength range of $900-200 \mathrm{~nm}$. The concentration of the solutions used for these measurements was $1 \cdot 10^{-2} \mathrm{M}$ (1 and 2) and $1 \cdot 10^{-3} \mathrm{M}(\mathbf{3 a} / \mathbf{b}$ and $\mathbf{4})$. The ${ }^{1} \mathrm{H}$ and ${ }^{13} \mathrm{C}$ NMR spectra of compounds $\mathbf{3 a} / \mathbf{b}$ and $\mathbf{4}$ were recorded at room temperature on a Varian Gemini 2000 spectrometer $\left({ }^{1} \mathrm{H}\right.$ at $200 \mathrm{MHz},{ }^{13} \mathrm{C}$ at $\left.50 \mathrm{MHz}\right) .5 .0 \mathrm{mg}$ of each compound was dissolved in $0.6 \mathrm{~mL}$ of DMSO- $d_{6}$ and transferred into a $5 \mathrm{~mm}$ NMR tube. Chemical shifts, $\delta$, are reported in ppm (parts per million) and scalar couplings, $J$, are reported in Hertz. Chemical shifts were calibrated relative to those of the solvent.

\subsection{Synthesis of copper(II) complexes 1 and $\mathbf{2}$}

Copper(II) complexes with 4,7-phenanthroline, [Cu( $\left.\mathrm{NO}_{3}\right)_{2}(4,7-$ Hphen $\left.)_{2}\right]\left(\mathrm{NO}_{3}\right)_{2}(\mathbf{1})$ and $\left[\mathrm{Cu}\left(\mathrm{CF}_{3} \mathrm{SO}_{3}\right)(4,7 \text {-phen })_{2}\left(\mathrm{H}_{2} \mathrm{O}\right)_{2}\right] \mathrm{CF}_{3} \mathrm{SO}_{3}(\mathbf{2})$ were synthesized according to the modified procedure for the preparation of copper(II) complexes with aromatic $N$-heterocycles [22]. The solution of $0.5 \mathrm{mmol}$ of $\mathrm{CuX} 2$ salt $\left(120.8 \mathrm{mg}\right.$ of $\mathrm{Cu}\left(\mathrm{NO}_{3}\right)_{2}-$ $.3 \mathrm{H}_{2} \mathrm{O}$ for 1 and $180.8 \mathrm{mg}$ of $\mathrm{Cu}\left(\mathrm{CF}_{3} \mathrm{SO}_{3}\right)_{2}$ for 2$)$ in $5.0 \mathrm{~mL}$ of ethanol was added slowly under stirring to the solution containing an equimolar amount of 4,7-phen $(90.1 \mathrm{mg}$ ) in $5.0 \mathrm{~mL}$ of ethanol. The reaction mixture was stirred at room temperature for 3-4 h. Complex 1 crystallized from the mother ethanol solution after its cooling in the refrigerator for three days, while those of complex $\mathbf{2}$ were obtained after recrystallization of the solid product precipitated from the reaction mixture in $10.0 \mathrm{~mL}$ of acetonitrile. The blue crystals of $\mathbf{1}$ and green crystals of $\mathbf{2}$ suitable for single-crystal $\mathrm{X}$-ray crystallography were filtered off and dried at ambient temperature. Yield (calculated on the basis of 4,7-phen): $99.4 \mathrm{mg}$ (59\%) for $\mathbf{1}$ and $127.0 \mathrm{mg}$ (67\%) for $\mathbf{2}$.

Anal. Calc. for $1\left(\mathrm{C}_{24} \mathrm{H}_{18} \mathrm{CuN}_{8} \mathrm{O}_{12} ; \mathrm{MW}=674.00\right)$ : C, 42.77; $\mathrm{H}$, 2.69; N, 16.63. Found: C, 42.64; H, 2.73; N, 16.58\%. IR (KBr, $v$, $\left.\mathrm{cm}^{-1}\right)$ : 3065w, 2931w $\left(v\left(\mathrm{C}_{\mathrm{ar}}-\mathrm{H}\right)\right), 1632 \mathrm{~m}, 1597 \mathrm{~m}, 1560 \mathrm{w}, 1500 \mathrm{~s}$ $\left(v\left(\mathrm{C}_{\mathrm{ar}}=\mathrm{C}_{\mathrm{ar}}\right)\right.$ and $\left.v\left(\mathrm{C}_{\mathrm{ar}}=\mathrm{N}\right)\right), 1385 \mathrm{~s}, 1356 \mathrm{~s}, 1324 \mathrm{~s}, 1280 \mathrm{vs}\left(v_{\mathrm{as}}\left(\mathrm{NO}_{3}\right)\right)$, $1242 \mathrm{~m}(v(\mathrm{C}-\mathrm{N})), 828 \mathrm{~m}, 634 \mathrm{~m}\left(\gamma\left(\mathrm{C}_{\mathrm{ar}}-\mathrm{H}\right)\right)$. UV-Vis (DMSO, $\lambda_{\max }$, $\mathrm{nm}): 839.0\left(\varepsilon=50.4 \mathrm{M}^{-1} \mathrm{~cm}^{-1}\right)$.

Anal. Calc. for $2\left(\mathrm{C}_{26} \mathrm{H}_{20} \mathrm{CuF}_{6} \mathrm{~N}_{4} \mathrm{O}_{8} \mathrm{~S}_{2} ; \mathrm{MW}=758.12\right)$ : C, 41.19; $\mathrm{H}$, 2.66; N, 7.39. Found: C, 41.05; H, 2.69; N, 7.42\%. IR (KBr, $\left.v, \mathrm{~cm}^{-1}\right)$ : 3407br $(v(\mathrm{O}-\mathrm{H})), 3080 \mathrm{w}, 3015 \mathrm{w}, 2903 \mathrm{w}\left(v\left(\mathrm{C}_{\mathrm{ar}}-\mathrm{H}\right)\right), 1629 \mathrm{w}$, $1604 \mathrm{w}, 1505 \mathrm{~m}, 1454 \mathrm{w}, 1445 \mathrm{w} \quad\left(v\left(\mathrm{C}_{\mathrm{ar}}=\mathrm{C}_{\mathrm{ar}}\right)\right.$ and $\left.v\left(\mathrm{C}_{\mathrm{ar}}=\mathrm{N}\right)\right)$, $1289 \mathrm{vs}, 1241 \mathrm{vs}, 1229 \mathrm{~s}\left(v_{\mathrm{as}}\left(\mathrm{SO}_{3}\right)\right), 1225 \mathrm{~s}\left(v_{\mathrm{s}}\left(\mathrm{CF}_{3}\right)\right), 1164 \mathrm{~s}, 1154 \mathrm{~s}$ $\left(v_{\mathrm{as}}\left(\mathrm{CF}_{3}\right)\right), 1026 \mathrm{vs}\left(v_{\mathrm{s}}\left(\mathrm{SO}_{3}\right)\right), 835 \mathrm{~m}, 639 \mathrm{~s}\left(\gamma\left(\mathrm{C}_{\mathrm{ar}}-\mathrm{H}\right)\right)$. UV-Vis (DMSO, $\left.\lambda_{\text {max }}, \mathrm{nm}\right): 839.0\left(\varepsilon=43.2 \mathrm{M}^{-1} \mathrm{~cm}^{-1}\right)$.

\subsection{Synthesis of $\mathbf{3 a} / \mathbf{b}$ and $\mathbf{4}$}

The solution of $\mathrm{CuX}$ salt $\left(0.5 \mathrm{mmol}, 120.8 \mathrm{mg}\right.$ of $\mathrm{Cu}\left(\mathrm{NO}_{3}\right)_{2} \cdot 3 \mathrm{H}_{2} \mathrm{O}$ for $\mathbf{3 a} / \mathbf{b}$ and $180.8 \mathrm{mg}$ of $\mathrm{Cu}\left(\mathrm{CF}_{3} \mathrm{SO}_{3}\right)_{2}$ for $\left.\mathbf{4}\right)$ in $5.0 \mathrm{~mL}$ of ethanol (3a and 4 ) or methanol (3b) was mixed with the solution of an equimolar amount of 1,7-phen $(90.1 \mathrm{mg}$ ) in $5.0 \mathrm{~mL}$ of ethanol (3a and $\mathbf{4}$ ) or methanol (3b). After addition of 1,7-phen, a solution changed color from blue to green, and no formation of metallic copper was observed. The reaction mixture was stirred at room temperature for 3-4 $\mathrm{h}$ and then left at room temperature to slowly evaporate. Crystals of compounds $\mathbf{3 a} \mathbf{a} \mathbf{b}$ were obtained from the mother solution, while those of compound $\mathbf{4}$ were obtained after 


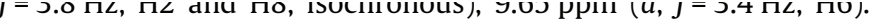
${ }^{13} \mathrm{C}$ NMR (50 MHz, DMSO- $d_{6}$ ): $\delta=122.68$ (C10), 123.30 (C4), 125.27 (C4a), 126.83 (C10a), 129.59 (C3), 131.57 (C9), 133.55 (C6), 135.93 (C5), 143.94 (C1a), 147.63 (C6a), 149.50 (C2), $154.92 \mathrm{ppm}(\mathrm{C} 8)$. IR $\left(\mathrm{KBr}, v, \mathrm{~cm}^{-1}\right)$ : 3053w, 2923w $\left(v\left(\mathrm{C}_{\mathrm{ar}}-\mathrm{H}\right)\right)$, $1622 \mathrm{~m}, 1596 \mathrm{w}, 1556 \mathrm{w}, 1434 \mathrm{~m}\left(v\left(\mathrm{C}_{\mathrm{ar}}=\mathrm{C}_{\mathrm{ar}}\right)\right.$ and $\left.v\left(\mathrm{C}_{\mathrm{ar}}=\mathrm{N}\right)\right), 1384 \mathrm{~s}$ $\left(v_{\text {as }}\left(\mathrm{NO}_{3}\right)\right), 840 \mathrm{~m}, 778 \mathrm{~m}\left(\gamma\left(\mathrm{C}_{\mathrm{ar}}-\mathrm{H}\right)\right)$. UV-Vis (DMSO, $\left.\lambda_{\max }, \mathrm{nm}\right)$ : $268.0\left(\varepsilon=2.0 \cdot 10^{5} \mathrm{M}^{-1} \mathrm{~cm}^{-1}\right)$.

Anal. Calc. for 3b $\left(\mathrm{C}_{12} \mathrm{H}_{9} \mathrm{~N}_{3} \mathrm{O}_{3} ; \mathrm{MW}=243.22\right)$ : C, 59.26; $\mathrm{H}, 3.73$; N, 17.28. Found: C, 58.96; H, 3.70; N, 17.20\%. The spectroscopic data are the same as those for $\mathbf{3 a}$.

Anal. Calc. for $4\left(\mathrm{C}_{13} \mathrm{H}_{9} \mathrm{~F}_{3} \mathrm{~N}_{2} \mathrm{O}_{3} \mathrm{~S}\right.$; $\left.\mathrm{MW}=330.28\right)$ : C, 47.27; $\mathrm{H}$, 2.75; N, 14.53. Found: C, 46.95; $\mathrm{H}, 2.62 ; \mathrm{N}, 14.27 \% .{ }^{1} \mathrm{H}$ NMR $\left(200 \mathrm{MHz}\right.$, DMSO- $\left.d_{6}\right): \delta=4.12(s$, broad, $\mathrm{NH}), 7.85(d d, J=8.1$, $4.4 \mathrm{~Hz}, \mathrm{H} 4), 7.98$ ( $m, \mathrm{H} 10), 8.12(d, J=8.8 \mathrm{~Hz}, \mathrm{H} 3), 8.34(d$, $J=9.1 \mathrm{~Hz}, \mathrm{H} 9), 8.62(d d, J=8.1,1.7 \mathrm{~Hz}, \mathrm{H} 5), 9.15$ (dd, $J=4.4$, $1.7 \mathrm{~Hz}, \mathrm{H} 2), 9.17(m, \mathrm{H} 8), 9.72 \mathrm{ppm}(d d, J=8.4 \mathrm{~Hz}, \mathrm{H} 6) .{ }^{13} \mathrm{C}$ NMR $\left(50 \mathrm{MHz}, \mathrm{DMSO}-d_{6}\right): \delta=122.85$ (C10), 123.41 (C4), 126.39 (C4a), 127.61 (C10a), 128.76 (C3), 131.06 (C9), 134.46 (C6), 136.61 (C5), 146.51 (C1a), 149.31 (C6a), 150.31 (C2), 152.70 ppm (C8). IR $\left(\mathrm{KBr}, \quad v, \mathrm{~cm}^{-1}\right)$ : 3077w, 2931w $\left(v\left(\mathrm{C}_{\mathrm{ar}}-\mathrm{H}\right)\right), 1638 \mathrm{~m}, 1626 \mathrm{~m}$, $1598 \mathrm{~m}, 1556 \mathrm{~m}, 1500 \mathrm{~m}, 1454 \mathrm{~m}, 1429 \mathrm{w}\left(v\left(\mathrm{C}_{\mathrm{ar}}=\mathrm{C}_{\mathrm{ar}}\right)\right.$ and $\left.v\left(\mathrm{C}_{\mathrm{ar}}=\mathrm{N}\right)\right)$, 1289vs, 1252vs $\left(v_{\text {as }}\left(\mathrm{SO}_{3}\right)\right)$, 1219vs $\left(v_{\mathrm{s}}\left(\mathrm{CF}_{3}\right)\right), 1160 \mathrm{vs}\left(\mathrm{vas}_{\mathrm{as}}\left(\mathrm{CF}_{3}\right)\right)$, 1030vs $\left(v_{\mathrm{s}}\left(\mathrm{SO}_{3}\right)\right), 857 \mathrm{~m}, 640 \mathrm{~s}\left(\gamma\left(\mathrm{C}_{\mathrm{ar}}-\mathrm{H}\right)\right)$. UV-Vis (DMSO, $\lambda_{\max }$, $\mathrm{nm}): 268.0\left(\varepsilon=2.3 \cdot 10^{5} \mathrm{M}^{-1} \mathrm{~cm}^{-1}\right)$.

\subsection{Crystallographic data collection and refinement of the structures}

Crystal data and details of the structure determinations are listed in Table 1. A suitable crystal was selected, and the crystal was mounted on a mylar loop in oil on a STOE IPDS 2 diffractometer. The crystals were kept at $200(2) \mathrm{K}$ for $\mathbf{1}, 250$ (2) for $\mathbf{2}$ and $\mathbf{3 a} \mathbf{a} \mathbf{b}$, and 298(2) K for 4 during data collection. Using olex2 [27], the structure was solved with the SHELXT [28] structure solution program using Intrinsic Phasing and refined with the sHeLxL [29] refinement package using Least Squares minimization. Hydrogen positions on aromatic rings were refined with riding coordinates with a fixed Uiso (1.2 times), pyridium $\mathrm{H}$ was refined with riding coordinates and stretchable bond (Uiso 1.2), and all $\mathrm{H}$ positions on water molecules were refined with restraints $(\mathrm{O}-\mathrm{H} 0.86(2)$, Uiso 1.5). In case of complex 2, 91 restraints have been used with oxygen atoms from water molecules defined with a similar Uiso; rigid body restraints were used on $\mathrm{F}$ - and $\mathrm{O}$-atoms of the different fluorosulfonate groups and the site of occupation factors (s.o.f.) of the fluorosulfonate anions were refined independently for each group (05, 06, 07 0.544(19); 011, 012, 013 0.913(4); 014, 015, 016 0.776(4)). Diamond [30] program was used to prepare drawings.

\subsection{Antimicrobial studies}

Test organisms for the antimicrobial assays were obtained from the National Collection of Type Cultures (NCTC) and the American the National

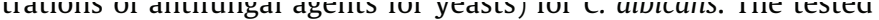
compounds were dissolved in DMSO at $50 \mathrm{mg} / \mathrm{mL}$. The highest concentration used was $400 \mu \mathrm{M}$. The inoculums were $10^{5}$ colony forming units, cfu/mL, for bacteria and $10^{4} \mathrm{cfu} / \mathrm{mL}$ for Candida spp. The MIC value was recorded as the lowest concentration that inhibited the growth after $24 \mathrm{~h}$ at $37^{\circ} \mathrm{C}$.

\subsection{In vitro cytotoxicity assay}

Cell viability was tested by the 3-(4,5-dimethylthiazol-2-yl)2,5-diphenyltetrazolium bromide (MTT) assay [31]. The assay was carried out using a monolayer $\left(1 \times 10^{4}\right.$ cells per well) of human lung fibroblast cell line (MRC-5) after $48 \mathrm{~h}$ of treatment with compounds at concentrations ranging from 4 to $400 \mu \mathrm{M}$. The MRC-5 cell line was maintained in RPMI 1640 medium (Roswell Park Memorial Institute medium), supplemented with $100 \mu \mathrm{g} / \mathrm{mL}$ streptomycin, $100 \mathrm{U} / \mathrm{mL}$ penicillin and $10 \%(\mathrm{v} / \mathrm{v})$ fetal bovine serum (FBS) (all from Sigma, Munich, Germany) as a monolayer and grown in humidified atmosphere of $95 \%$ air and $5 \% \mathrm{CO}_{2}$ at $37^{\circ} \mathrm{C}$. The extent of MTT reduction was measured spectrophotometrically at $540 \mathrm{~nm}$ using a Tecan Infinite 200 Pro multiplate reader (Tecan Group Ltd., Männedorf, Switzerland), and the cell survival was expressed as percentage of the control (untreated cells). The percentage of viability values were plotted against the log of concentration and a sigmoidal dose response curve was calculated by non-linear regression analysis, using the Graphpad Prism software, version 5.0 for Windows (Graphpad Software, CA, USA). Cytotoxicity is expressed as the concentration of the compound inhibiting growth by $50 \%\left(\mathrm{IC}_{50}\right)$.

\section{Results and discussion}

\subsection{Different coordination abilities of 1,7- and 4,7-phen in the reaction with $\mathrm{Cu}(\mathrm{II})$}

Two aromatic $N$-heterocycles, 1,7- and 4,7-phenanthroline (1,7and 4,7-phen) were used as ligands for the complexation to $\mathrm{Cu}(\mathrm{II})$ ion (Scheme $1 \mathrm{a}$ and $\mathrm{b}$ ). When the reactions were performed by mixing equimolar amounts of $\mathrm{CuX}_{2}$ salts $\left(\mathrm{X}=\mathrm{NO}_{3}^{-}\right.$and $\left.\mathrm{CF}_{3} \mathrm{SO}_{3}^{-}\right)$ and 4,7-phen in ethanol as solvent at room temperature, the [Cu $\left.\left(\mathrm{NO}_{3}\right)_{2}(4,7-\mathrm{Hphen})_{2}\right]\left(\mathrm{NO}_{3}\right)_{2}(\mathbf{1})$ and $\left[\mathrm{Cu}\left(\mathrm{CF}_{3} \mathrm{SO}_{3}\right)(4,7 \text {-phen })_{2}\left(\mathrm{H}_{2} \mathrm{O}\right)_{2}\right]$ $\mathrm{CF}_{3} \mathrm{SO}_{3}(2)$ complexes were obtained as final products (Scheme $1 \mathrm{a}$ ). On the other hand, in the reactions of these two $\mathrm{Cu}$ (II) salts with 1,7-phen under the same experimental conditions, only 1,7$\mathrm{HphenNO}_{3}(\mathbf{3 a})$ and $1,7-\mathrm{HphenCF} \mathrm{SO}_{3}(\mathbf{4})$ were isolated as reaction products (Scheme $1 \mathrm{~b}$ ). Furthermore, in the reaction between equimolar amounts of $\mathrm{Cu}\left(\mathrm{NO}_{3}\right)_{2}$ and 1,7-phen in methanol as the solvent, the product $1,7-\mathrm{HphenNO}_{3}(\mathbf{3 b})$, which is a conformational polymorph of 3a (vide infra), was obtained.

\subsubsection{Description of the single crystal structures}

The molecular structures of the copper(II) complexes $\mathbf{1}$ and $\mathbf{2}$ 
Table 1

Details of the crystal structure determinations of 1-4.

\begin{tabular}{|c|c|c|c|c|c|}
\hline & 1 & 2 & $3 a$ & $\mathbf{3 b}$ & 4 \\
\hline Empirical formula & $\mathrm{C}_{24} \mathrm{H}_{18} \mathrm{CuN}_{8} \mathrm{O}_{12}$ & $\mathrm{C}_{26} \mathrm{H}_{20} \mathrm{CuF}_{6} \mathrm{~N}_{4} \mathrm{O}_{8} \mathrm{~S}_{2}$ & $\mathrm{C}_{12} \mathrm{H}_{9} \mathrm{~N}_{3} \mathrm{O}_{3}$ & $\mathrm{C}_{12} \mathrm{H}_{9} \mathrm{~N}_{3} \mathrm{O}_{3}$ & $\mathrm{C}_{13} \mathrm{H}_{9} \mathrm{~F}_{3} \mathrm{~N}_{2} \mathrm{O}_{3} \mathrm{~S}$ \\
\hline CCDC number & 1918878 & 1918879 & 1918880 & 1918881 & 1918882 \\
\hline Formula weight (g/mol) & 674.00 & 758.12 & 243.22 & 243.22 & 330.28 \\
\hline Crystal system, space group & triclinic, $P \overline{1}$ & triclinic, $P_{1}$ & monoclinic, $C 2 / c$ & monoclinic, $P 2_{1} / n$ & triclinic, $P \overline{1}$ \\
\hline$a(\AA)$ & $5.7292(4)$ & $12.1353(7)$ & $25.807(4)$ & $12.5360(17)$ & $6.2066(9)$ \\
\hline$b(\AA)$ & $6.9657(4)$ & $13.9034(9)$ & $3.7004(5)$ & $6.7791(6)$ & $10.0237(16)$ \\
\hline$c(\AA)$ & $16.9586(11)$ & $19.1860(12)$ & $24.199(3)$ & $13.3532(18)$ & $12.1087(17)$ \\
\hline$\alpha\left({ }^{\circ}\right)$ & $88.620(5)$ & $69.443(5)$ & & & $100.201(12)$ \\
\hline$\beta\left(^{\circ}\right)$ & $87.931(5)$ & $85.859(5)$ & $115.780(9)$ & $112.306(10)$ & $104.259(11)$ \\
\hline$\gamma\left({ }^{\circ}\right)$ & $69.129(5)$ & $70.392(5)$ & & & $102.899(12)$ \\
\hline$V\left(\AA^{3}\right)$ & $631.92(7)$ & $2851.4(3)$ & $2080.9(5)$ & $1049.9(2)$ & $689.88(19)$ \\
\hline$F_{000}$ & 343 & 1532 & 1008 & 504 & 336 \\
\hline$Z$ & 1 & 2 & 8 & 4 & 2 \\
\hline $\mathrm{X}$-radiation, $\lambda / \AA$ & Mo K $\alpha 0.71073$ & Mo K $\alpha 0.71073$ & Мo K $\alpha 0.71073$ & Mo K $\alpha 0.71073$ & Mo $\mathrm{K} \alpha 0.71073$ \\
\hline Data collect. $T(\mathrm{~K})$ & $200(2)$ & $250(2)$ & $250(2)$ & $250(2)$ & $298(2)$ \\
\hline Calculated density $\left(\mathrm{Mg} / \mathrm{m}^{3}\right)$ & 1.771 & 1.766 & 1.553 & 1.539 & 1.590 \\
\hline Absorption coefficient $\left(\mathrm{mm}^{-1}\right)$ & 0.952 & 1.010 & 0.115 & 0.114 & 0.284 \\
\hline Crystal size $\left(\mathrm{mm}^{3}\right)$ & $0.110 \times 0.083 \times 0.060$ & $0.64 \times 0.26 \times 0.05$ & $0.54 \times 0.21 \times 0.05$ & $0.48 \times 0.19 \times 0.05$ & $0.47 \times 0.2 \times 0.03$ \\
\hline $2 \theta$ range $\left(^{\circ}\right)$ & 2.4 to 50.4 & 3.3 to 53.8 & 3.5 to 52.9 & 3.8 to 52.5 & 3.6 to 52.5 \\
\hline Index ranges $h, k, l$ & $\begin{array}{l}-6 \ldots 6,-8 \ldots 8,-20 \\
\ldots 20\end{array}$ & $\begin{array}{l}-15 \ldots 15,-17 \ldots 17 \\
-24 \ldots 24\end{array}$ & $\begin{array}{l}-31 \ldots 31,-4 \ldots 4 \\
-30 \ldots 30\end{array}$ & $\begin{array}{l}-15 \ldots 15,-8 \ldots 8 \\
-16 \ldots 16\end{array}$ & $\begin{array}{l}-7 \ldots 7,-12 \ldots 12 \\
-15 \ldots 15\end{array}$ \\
\hline $\begin{array}{l}\text { No. of collected and independent } \\
\text { reflections }\end{array}$ & 8217,2248 & 43913,12144 & 9348,2114 & 11820,2113 & 8320,2770 \\
\hline$R_{\text {int }}$ & 0.0567 & 0.0959 & 0.0863 & 0.0873 & 0.0706 \\
\hline Data/restraints/parameters & $2248 / 0 / 206$ & $12144 / 91 / 925$ & $2114 / 0 / 168$ & $2113 / 0 / 166$ & $2770 / 0 / 203$ \\
\hline Goodness-on-fit on $F^{2}$ & 1.008 & 1.014 & 1.082 & 0.985 & 0.977 \\
\hline Final $R$ indices $[I \geq 2 \sigma(I)]$ & $0.0386,0.0869$ & $0.0487,0.1052$ & $0.0741,0.1234$ & $0.0648,0.1498$ & $0.0521,0.0995$ \\
\hline Final $R$ indices (all data) & $0.0551,0.0928$ & $0.0880,0.1233$ & $0.1919,0.1707$ & $0.1646,0.2000$ & $0.1898,0.1394$ \\
\hline Difference density: $\max , \min \left(\mathrm{e} / \AA^{3}\right)$ & $0.382,-0.460$ & $0.75,-0.54$ & $0.22,-0.20$ & $0.20,-0.21$ & $0.18,-0.18$ \\
\hline
\end{tabular}

a)

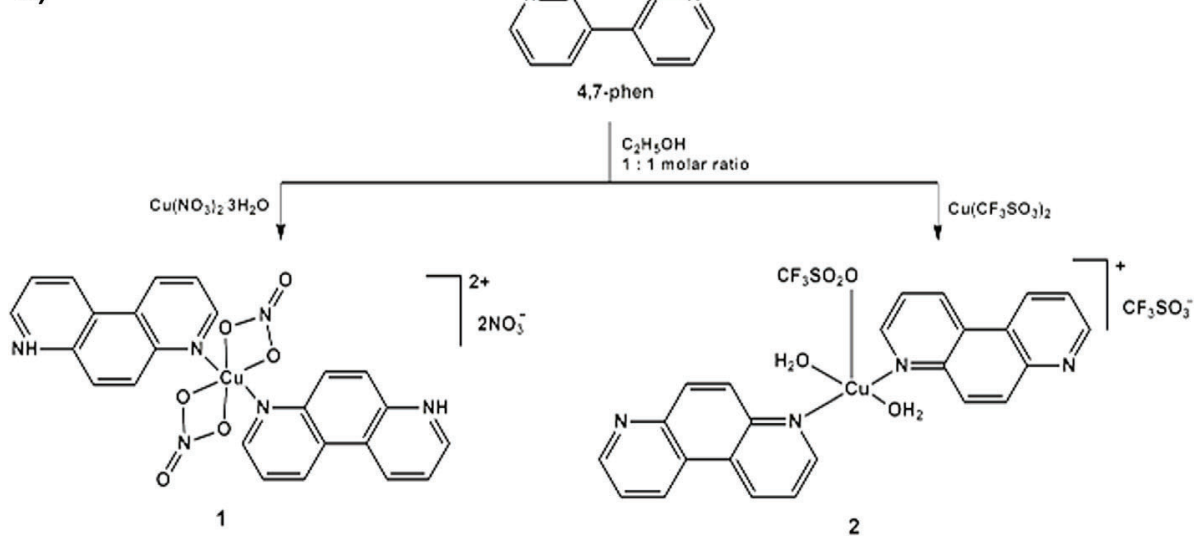

b)
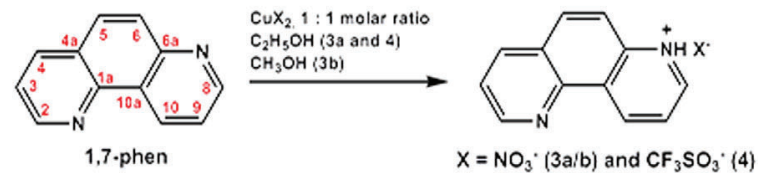

Scheme 1. Schematic presentation of the reactions between $\mathrm{CuX}_{2}$ salts $\left(\mathrm{X}=\mathrm{NO}_{3}^{-}\right.$and $\left.\mathrm{CF}_{3} \mathrm{SO}_{3}^{-}\right)$and (a) 4,7-phen and (b) 1,7-phen. The numbering scheme of carbon atoms in 1,7-phen is in accordance with IUPAC recommendations for fused ring systems.

In complex $\mathbf{1}$, the $\mathrm{Cu}(\mathrm{II})$ ion is located at an inversion center and has a distorted octahedral environment (Fig. 1 and Table 2). The $\mathrm{Cu}$ (II) ion is coordinated by two nitrate anions bidentately and two protonated 4,7-Hphen ${ }^{+}$ligands which act in a monodentate fashion. The average $\mathrm{Cu}-\mathrm{N}(4,7-$ phen) and $\mathrm{Cu}-\mathrm{O}$ (nitrate) bond distances compare well to those in the previously characterized copper(II) complexes containing the 4,7-phenanthroline moiety [32-35] and/or other aromatic $N$-heterocycles [22]. Uncoordinated nitrogen atoms (N2) in both 4,7-phen ligands of $\mathbf{1}$ are protonated and act as donors in hydrogen bonding with oxygen atoms of nitrate counter-ions (Table 3 ). Contrary to the complex $\mathbf{1}$, in the previously characterized $\left[\mathrm{CuX}_{2}(4,7 \text {-phen })_{2}\right]$ complexes $\left(\mathrm{X}=\mathrm{Cl}^{-}\right.$, $\mathrm{Br}^{-}$and $\mathrm{NO}_{3}^{-}$), the $\mathrm{Cu}(\mathrm{II})$ ion has square planar geometry and is coordinated by two 4,7-phen ligands and two X anions [32]. However, in the latter complexes, no protonation of the uncoordinated nitrogen atoms was observed [32]. The protonation of nitrogen 

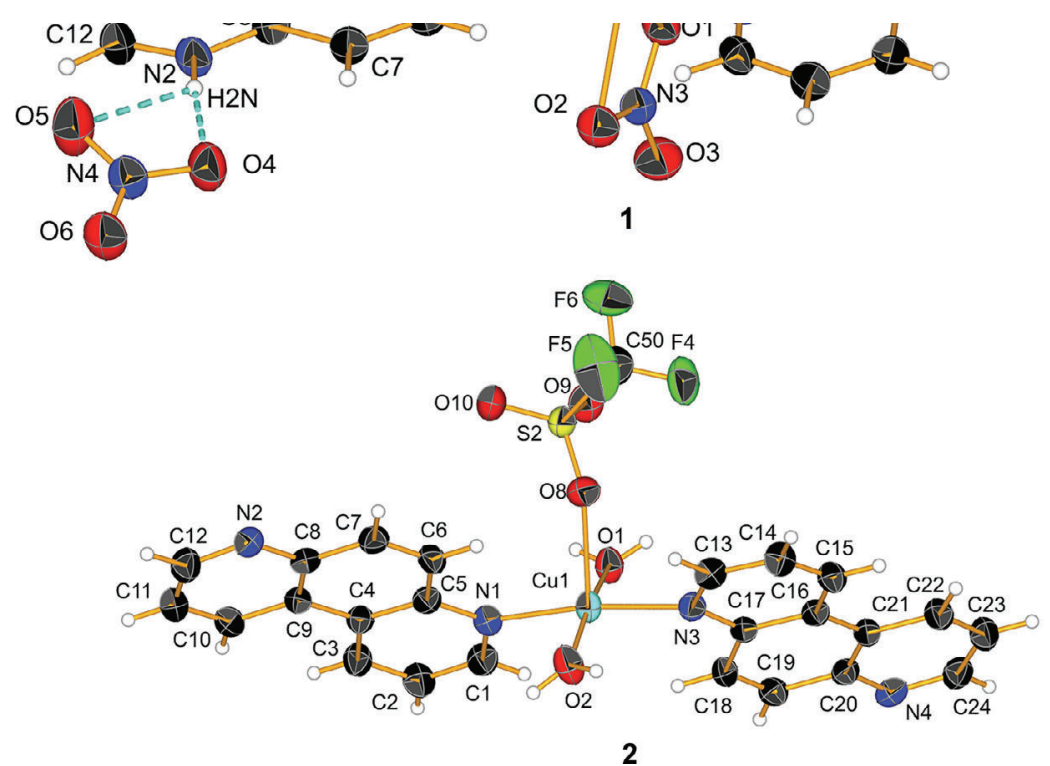

Fig. 1. Molecular structures of copper(II) complexes $\mathbf{1}(\# 1:-x+2,-y+1,-z+1)$ and $\mathbf{2}$. Non-coordinating nitrates (1) are connected with the phenanthrolinium parts via hydrogen bonds, while triflate counter-anion (2) is omitted for clarity. Only one of the two independent moieties of $\mathbf{2}$ is shown. Displacement ellipsoids are drawn at $50 \%$ probability level and $\mathrm{H}$ atoms are represented by spheres of arbitrary size.

atom of 4,7-phen was also previously noticed for copper(I) complexes, e.g. $\left[\left\{\mathrm{Cu}_{2}(4,7-\right.\right.$ phen $\left.\left.)(4,7-\mathrm{Hphen})_{2}\right\} \mathrm{Mo}_{12} \mathrm{AsO}_{4}\right] \cdot 2.66 \mathrm{H}_{2} \mathrm{O}[36]$ and $\left[\mathrm{Cu}(\mathrm{NCS})_{2}(4,7-\mathrm{Hphen})\right]_{\mathrm{n}} \quad[37]$, characterized by X-ray crystallography.

The coordination geometry around $\mathrm{Cu}(\mathrm{II})$ in $\mathbf{2}$ is square pyramidal (Figs. 1 and S1), as can be deduced from the trigonality index $\tau$ of $0.04 / 0.002 \quad[38], \quad \tau=(\beta-\alpha) / 60^{\circ}$ where $\beta=\mathrm{N} 1-\mathrm{Cu} 1-\mathrm{N} 3 /$ O3-Cu2-O4 $=171.05(12) / 170.82(14)^{\circ}$ and $\alpha=01-\mathrm{Cu} 1-\mathrm{O} 2 /$ $\mathrm{N} 5-\mathrm{Cu} 2-\mathrm{N} 7=168.57(13) / 170.17(13)^{\circ}$. The perfect square pyramidal and trigonal bipyramidal geometries result in $\tau$ values of 0 and 1 , respectively [38]. The $\mathrm{Cu}(\mathrm{II})$ ion is equatorially coordinated by two nitrogen atoms of 4,7-phen and two oxygen atoms of water molecules. The remaining coordination site at the axial position in $\mathbf{2}$ is occupied by a triflate oxygen atom. As a consequence of a pseudo-Jahn-Teller distortion, the axial $\mathrm{Cu}-08 / 6 \mathrm{~A}$ (triflate) bond $(2.383(3) / 2.373(11) \AA$ ) is significantly longer than the equatorial $\mathrm{Cu}-\mathrm{O}$ (water) and $\mathrm{Cu}-\mathrm{N}(4,7$-phen) bonds (Table 2). As can be seen from Fig. 1, the coordinated triflate anion adopts a staggered ethane-like conformation around the $\mathrm{S}-\mathrm{C}$ bond.

The molecular structures of compounds $\mathbf{3 a}$ and $\mathbf{4}$ with the crystallographic numbering scheme are shown in Fig. 2, while that of $\mathbf{3 b}$ is given in Supplementary Information (Fig. S2). The structures of $\mathbf{3 a}$ and $\mathbf{3 b}$ have the same phenanthrolinium and nitrate parts, however the angle between these two parts is different. Indeed, the angle formed by the intersection of the two planes (the first one contains the phenanthrolinium, the second one the nitrate ion, respectively, blue and red planes in Fig. 3.) in $\mathbf{3 a}$ and $\mathbf{3 b}$ amounts to ca. 20 and $8^{\circ}$, respectively (Fig. 3). This difference in be concluded that compounds $\mathbf{3 a}$ and $\mathbf{3 b}$ are conformational polymorphs.

Contrary to our results, the reactions of copper(I) halide with 1,7-phen in acetonitrile led to the formation of polynuclear copper(I) complexes, in which this ligand is monodentately coordinated to the $\mathrm{Cu}(\mathrm{I})$ ion via the less sterically hindered N7 nitrogen, as was shown by X-ray crystallography [39].

\subsubsection{Spectroscopic characterization}

The spectroscopic data for the copper(II) complexes $\mathbf{1}$ and $\mathbf{2}$ and 1,7-phenanthrolinium salts $\mathbf{3 a} / \mathbf{b}$ and $\mathbf{4}$ are presented in the Experimental section (vide supra).

Copper(II) complexes 1 and $\mathbf{2}$ exhibit a single broad and symmetric band in the expected region [40], which can be assigned to the $d_{z}{ }^{2}, d_{x y}, d_{x z}, d_{y z} \rightarrow d_{x-y}^{2}{ }^{2}$ transitions with a $d_{x-y}^{2}{ }^{2}$ ground state [41]. The shape of the UV-Vis spectra and position of maximum absorption of $\mathbf{1}$ and $\mathbf{2}$ are in accordance with those reported for the other copper(II) complexes with aromatic $N$-heterocycles [22]. In compounds $\mathbf{3} \mathbf{a} / \mathbf{b}$ and $\mathbf{4}$, the corresponding absorbance peak at $268.0 \mathrm{~nm}$ can be attributed to $\pi \rightarrow \pi^{*}$ transitions in 1,7-Hphen ${ }^{+}$[24].

The IR spectra of the products 1-4 display the bands due to the coordinated and/or protonated $\mathrm{N}$-heterocycle and the corresponding anion $\mathrm{X}\left(\mathrm{X}=\mathrm{NO}_{3}^{-}\right.$and $\left.\mathrm{CF}_{3} \mathrm{SO}_{3}^{-}\right)$. A band originated from the nitrate asymmetric stretching vibrations in the IR spectrum of copper(II) complex $\mathbf{1}$ is split into four strong intensity bands, which is an indication of the presence of coordinated nitrate which also participates in the hydrogen bonding interactions and nitrate incorporated in the crystal lattice as counter-ion $[42,43]$. Similarly, the IR 
Table 2

Selected bond distances $(\AA)$ and valence angles $\left(^{\circ}\right)$ in copper(II) complexes $\mathbf{1}$ and $\mathbf{2}$.

\begin{tabular}{|c|c|c|c|}
\hline \multicolumn{2}{|l|}{1} & \multicolumn{2}{|l|}{2} \\
\hline $\mathrm{Cu} 1-\mathrm{O} 1$ & $1.992(2)$ & $\mathrm{Cu} 1-\mathrm{O} 1$ & $1.960(3)$ \\
\hline $\mathrm{Cu} 1-\mathrm{O} 1^{\mathrm{i}}$ & $1.992(2)$ & $\mathrm{Cu} 1-\mathrm{O} 2$ & $1.941(3)$ \\
\hline $\mathrm{Cu} 1-\mathrm{N} 1^{\mathrm{i}}$ & $2.007(2)$ & $\mathrm{Cu} 1-\mathrm{O} 8$ & $2.383(3)$ \\
\hline $\mathrm{Cu} 1-\mathrm{N} 1$ & $2.007(2)$ & $\mathrm{Cu} 1-\mathrm{N} 1$ & $2.028(3)$ \\
\hline $\mathrm{Cu} 1-\mathrm{O} 2$ & $2.446(2)$ & $\mathrm{Cu} 1-\mathrm{N} 3$ & $2.021(3)$ \\
\hline \multirow[t]{5}{*}{$\mathrm{Cu} 1-\mathrm{O} 2^{\mathrm{i}}$} & $2.446(2)$ & $\mathrm{Cu} 2-\mathrm{O} 3$ & $1.935(3)$ \\
\hline & & $\mathrm{Cu} 2-\mathrm{O} 4$ & $1.953(3)$ \\
\hline & & $\mathrm{Cu} 2-\mathrm{N} 5$ & $2.027(3)$ \\
\hline & & $\mathrm{Cu} 2-\mathrm{N} 7$ & $2.041(3)$ \\
\hline & & $\mathrm{Cu} 2-06 \mathrm{~A}$ & $2.373(11)$ \\
\hline $\mathrm{O} 1-\mathrm{Cu} 1-\mathrm{O} 1^{\mathrm{i}}$ & $180.00(10)$ & $\mathrm{O} 1-\mathrm{Cu} 1-\mathrm{O} 8$ & $90.39(11)$ \\
\hline $\mathrm{O} 1-\mathrm{Cu} 1-\mathrm{N} 1^{\mathrm{i}}$ & $90.40(9)$ & O1-Cu1-N1 & $88.22(12)$ \\
\hline $\mathrm{O} 1^{\mathrm{i}}-\mathrm{Cu} 1-\mathrm{N} 1^{\mathrm{i}}$ & 89.60(9) & $\mathrm{O} 1-\mathrm{Cu} 1-\mathrm{N} 3$ & $90.56(11)$ \\
\hline O1-Cu1-N1 & $89.60(9)$ & $\mathrm{O} 1-\mathrm{Cu} 1-\mathrm{O} 2$ & $168.57(13)$ \\
\hline 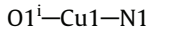 & $90.40(9)$ & $\mathrm{O} 2-\mathrm{Cu} 1-\mathrm{O} 8$ & $101.04(12)$ \\
\hline $\mathrm{N} 1{ }^{\mathrm{i}}-\mathrm{Cu} 1-\mathrm{N} 1$ & 180.0 & $\mathrm{O} 2-\mathrm{Cu} 1-\mathrm{N} 1$ & $89.23(12)$ \\
\hline 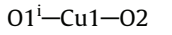 & $122.74(8)$ & $\mathrm{O} 2-\mathrm{Cu} 1-\mathrm{N} 3$ & $90.23(12)$ \\
\hline $\mathrm{O} 1-\mathrm{Cu} 1-\mathrm{O} 2$ & $57.26(8)$ & $\mathrm{N} 1-\mathrm{Cu} 1-\mathrm{O} 8$ & $101.78(11)$ \\
\hline $\mathrm{N} 1-\mathrm{Cu} 1-\mathrm{O} 2$ & $90.02(8)$ & $\mathrm{N} 3-\mathrm{Cu} 1-\mathrm{O} 8$ & $87.09(11)$ \\
\hline $\mathrm{N} 1{ }^{\mathrm{i}}-\mathrm{Cu} 1-\mathrm{O} 2$ & $89.98(9)$ & $\mathrm{N} 1-\mathrm{Cu} 1-\mathrm{N} 3$ & $171.05(12)$ \\
\hline $\mathrm{C} 1-\mathrm{N} 1-\mathrm{Cu} 1$ & $116.37(19)$ & $\mathrm{S} 2-\mathrm{O} 8-\mathrm{Cu} 1$ & $138.02(18)$ \\
\hline $\mathrm{C} 5-\mathrm{N} 1-\mathrm{Cu} 1$ & $125.32(18)$ & $\mathrm{C} 1-\mathrm{N} 1-\mathrm{Cu} 1$ & $113.3(2)$ \\
\hline N3-O1-Cu1 & $102.36(16)$ & $\mathrm{C} 5-\mathrm{N} 1-\mathrm{Cu} 1$ & $128.1(2)$ \\
\hline \multirow[t]{15}{*}{ N3-O2-Cu1 } & $82.49(16)$ & $\mathrm{C} 13-\mathrm{N} 3-\mathrm{Cu} 1$ & $116.6(2)$ \\
\hline & & $\mathrm{C} 17-\mathrm{N} 3-\mathrm{Cu} 1$ & $124.0(2)$ \\
\hline & & $\mathrm{O} 3-\mathrm{Cu} 2-\mathrm{O} 4$ & $170.82(14)$ \\
\hline & & $\mathrm{O} 3-\mathrm{Cu} 2-\mathrm{N} 5$ & $89.09(12)$ \\
\hline & & $\mathrm{O} 3-\mathrm{Cu} 2-\mathrm{N} 7$ & $90.11(11)$ \\
\hline & & $\mathrm{O} 3-\mathrm{Cu} 2-\mathrm{O} 6 \mathrm{~A}$ & $103.1(3)$ \\
\hline & & $\mathrm{O} 4-\mathrm{Cu} 2-\mathrm{N} 5$ & 89.56(11) \\
\hline & & $\mathrm{O} 4-\mathrm{Cu} 2-\mathrm{N} 7$ & 89.67(11) \\
\hline & & $\mathrm{O} 4-\mathrm{Cu} 2-\mathrm{O} 6 \mathrm{~A}$ & $85.9(3)$ \\
\hline & & N5-Cu2-N7 & $170.17(13)$ \\
\hline & & $\mathrm{N} 5-\mathrm{Cu} 2-\mathrm{O} 6 \mathrm{~A}$ & $86.5(3)$ \\
\hline & & $\mathrm{N} 7-\mathrm{Cu} 2-\mathrm{O} 6 \mathrm{~A}$ & 103.2(3) \\
\hline & & $\mathrm{S} 1-\mathrm{O} 6 \mathrm{~A}-\mathrm{Cu} 2$ & $137.9(6)$ \\
\hline & & $\mathrm{C} 25-\mathrm{N} 5-\mathrm{Cu} 2$ & $117.0(2)$ \\
\hline & & $\mathrm{C} 29-\mathrm{N} 5-\mathrm{Cu} 2$ & $122.5(2)$ \\
\hline \multirow{2}{*}{\multicolumn{2}{|c|}{$\begin{array}{l}\text { Symmetry code: (i) }-x+2,-y+1 \text {, } \\
\quad-z+1\end{array}$}} & C37-N7-Cu2 & $115.5(2)$ \\
\hline & & $\mathrm{C} 41-\mathrm{N} 7-\mathrm{Cu} 2$ & $125.2(2)$ \\
\hline
\end{tabular}

with that of $\mathrm{Cu}\left(\mathrm{CF}_{3} \mathrm{SO}_{3}\right)_{2}$ salt, the band at $1289 \mathrm{~cm}^{-1}$ can be attributed to the $v_{\text {as }}(\mathrm{S}-\mathrm{O})$ of the $\mathrm{CF}_{3} \mathrm{SO}_{3}^{-}$counter-anion, while those at 1240 and $1229 \mathrm{~cm}^{-1}$ are due to the same vibrations of the monodentately coordinated triflate [44-46]. Contrary to this, in the IR spectrum of $\mathbf{3 a} / \mathbf{b}$, only one very strong band at $1384 \mathrm{~cm}^{-1}$ due to the $v_{\text {as }}\left(\mathrm{NO}_{3}\right)$ is observed, indicating that the nitrate solely acts as counter-ion $[42,43]$, while in that of $\mathbf{4}$, the band due to the $v_{\mathrm{as}}\left(\mathrm{SO}_{3}\right)$ is split into two bands ( 1289 and $1252 \mathrm{~cm}^{-1}$ ) as a consequence of its participation in the hydrogen bonding interactions [47].

The protonation of the N7 nitrogen atom in 1,7-phen in compounds $\mathbf{3 a} / \mathbf{b}$ and $\mathbf{4}$ is also evident from ${ }^{1} \mathrm{H}$ NMR spectra; a broad singlet at 3.80 and $4.12 \mathrm{ppm}$, respectively, was noted. Moreover, the protonation process changes the electronic features of 1,7phen, resulting in the appearance of eight proton signals in the spectra of $\mathbf{3 a / b}$ and $\mathbf{4}$, instead of five in that of 1,7-phen [24].

\subsection{Antimicrobial and cytotoxic activity of the copper(II) complexes $\mathbf{1}$ and 2}

Given the traditional antimicrobial properties shown by copper-containing surfaces and complexes [11-21], the activity of the newly synthesized copper(II) complexes $\mathbf{1}$ and 2, along with $\mathrm{CuX}_{2}$ salts $\left(\mathrm{X}=\mathrm{NO}_{3}^{-}\right.$and $\left.\mathrm{CF}_{3} \mathrm{SO}_{3}^{-}\right)$used for their synthesis, were evaluated against two Gram-positive (S. aureus and L. monocytogenes) and two Gram-negative bacteria (P. aeruginosa and E. coli) as well as the fungus $C$. albicans (Table 4). It was found previously that 4,7-phen did not exert significant antimicrobial activity against the investigated strains, yet had a slight cytotoxic effect on the MRC-5 cell line $[25,26]$. While $\mathrm{CuX}_{2}$ salts were not active against the investigated strains at concentrations lower than $400 \mu \mathrm{M}, 1$ and $\mathbf{2}$ showed slightly better growth inhibiting activity, suggesting that the antimicrobial effect of the complexes is multifactorial. The complexes $\mathbf{1}$ and $\mathbf{2}$ exhibited comparable activity, with $\mathbf{1}$ being slightly more active against the tested strains. The efficiency of the complexes $\mathbf{1}$ and $\mathbf{2}$ was higher than that shown by copper(II) complexes with aromatic $N$-heterocycles, pyrimidine, pyrazine, quinazoline and phthalazine [22], but significantly lower than

Table 3

Hydrogen bond parameters for 1-4.

\begin{tabular}{|c|c|c|c|c|}
\hline$D-\mathrm{H} \cdots A$ & $D-\mathrm{H}(\AA)$ & $H \cdots A(\AA)$ & $D \cdots A(\AA)$ & $D-\mathrm{H} \cdots A\left({ }^{\circ}\right)$ \\
\hline \multicolumn{5}{|l|}{1} \\
\hline N2-H2N...O4 & 0.88 & 1.95 & $2.825(3)$ & 172.6 \\
\hline $\mathrm{N} 2-\mathrm{H} 2 \mathrm{~N} \ldots \mathrm{O} 5^{\mathrm{i}}$ & 0.88 & 2.36 & $2.971(4)$ & 127.0 \\
\hline \multicolumn{5}{|c|}{ Symmetry code: (i) $-x+2,-y+1,-z+1$} \\
\hline \multicolumn{5}{|l|}{2} \\
\hline $\mathrm{O} 1-\mathrm{H} 1 \mathrm{~A} \ldots \mathrm{N} 6^{\mathrm{i}}$ & $0.837(18)$ & $1.938(19)$ & $2.774(4)$ & $178(5)$ \\
\hline $\mathrm{O} 1-\mathrm{H} 1 \mathrm{~B} \ldots \mathrm{O} 9^{\mathrm{ii}}$ & $0.843(18)$ & $1.864(19)$ & $2.707(4)$ & $178(4)$ \\
\hline $\mathrm{O} 2-\mathrm{H} 2 \mathrm{~A} \ldots \mathrm{O} 11^{\mathrm{iii}}$ & $0.834(18)$ & $1.926(19)$ & $2.752(5)$ & $171(4)$ \\
\hline $\mathrm{O} 2-\mathrm{H} 2 \mathrm{~B} \ldots \mathrm{N} 8$ & $0.852(18)$ & $1.87(2)$ & $2.708(4)$ & $169(5)$ \\
\hline О3-Н3А. .014 & $0.844(18)$ & $1.93(2)$ & $2.762(5)$ & $168(5)$ \\
\hline O3-Н3А. .015A & $0.844(18)$ & $2.16(5)$ & $2.748(15)$ & $127(5)$ \\
\hline $\mathrm{O} 3-\mathrm{H} 3 \mathrm{~B} \ldots \mathrm{N} 4^{\mathrm{iii}}$ & $0.853(18)$ & $1.843(19)$ & $2.696(4)$ & $178(4)$ \\
\hline $\mathrm{O} 4-\mathrm{H} 4 \mathrm{~A} \ldots \mathrm{N} 2^{\mathrm{iv}}$ & $0.844(18)$ & $1.889(18)$ & $2.730(4)$ & $174(4)$ \\
\hline $\mathrm{O} 4-\mathrm{H} 4 \mathrm{~B} \ldots \mathrm{O} 7^{\mathrm{iv}}$ & $0.845(18)$ & $1.96(3)$ & $2.736(7)$ & $153(5)$ \\
\hline \multicolumn{5}{|c|}{ Symmetry codes: (i) $x, y-1, z+1$; (ii) $-x+1,-y,-z+1$; (iii) $-x+1,-y+1,-z+1$; (iv) $-x+1,-y+1,-z$} \\
\hline \multicolumn{5}{|l|}{$3 a$} \\
\hline N1-H1A. . O1 & $0.98(4)$ & $1.74(4)$ & $2.724(5)$ & $174(4)$ \\
\hline N1-H1A...O2 & $0.98(4)$ & $2.39(4)$ & $3.075(5)$ & $126(3)$ \\
\hline \multicolumn{5}{|l|}{$\mathbf{3 b}$} \\
\hline N1-H1A. . O1 & $0.97(4)$ & $1.70(4)$ & $2.665(4)$ & $179(4)$ \\
\hline N1-H1A...O2 & $0.97(4)$ & $2.47(4)$ & $3.076(4)$ & $120(3)$ \\
\hline \multicolumn{5}{|l|}{4} \\
\hline $\mathrm{N} 1-\mathrm{H} 1 \mathrm{~A} \ldots \mathrm{O} 1^{\mathrm{i}}$ & $0.96(4)$ & $1.88(4)$ & $2.838(4)$ & $176(4)$ \\
\hline Symmetry code: ( & & & & \\
\hline
\end{tabular}


$3 a$

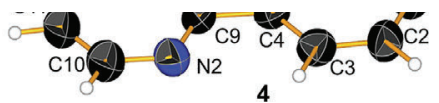

Fig. 2. Molecular structures of 3a and $\mathbf{4}$. Displacement ellipsoids are drawn at 50\% probability level for $\mathbf{3}$ and $35 \%$ for $\mathbf{4}$ and $\mathrm{H}$ atoms are represented by spheres of arbitrary size. Hydrogen bonds are drawn as dashed blue lines.

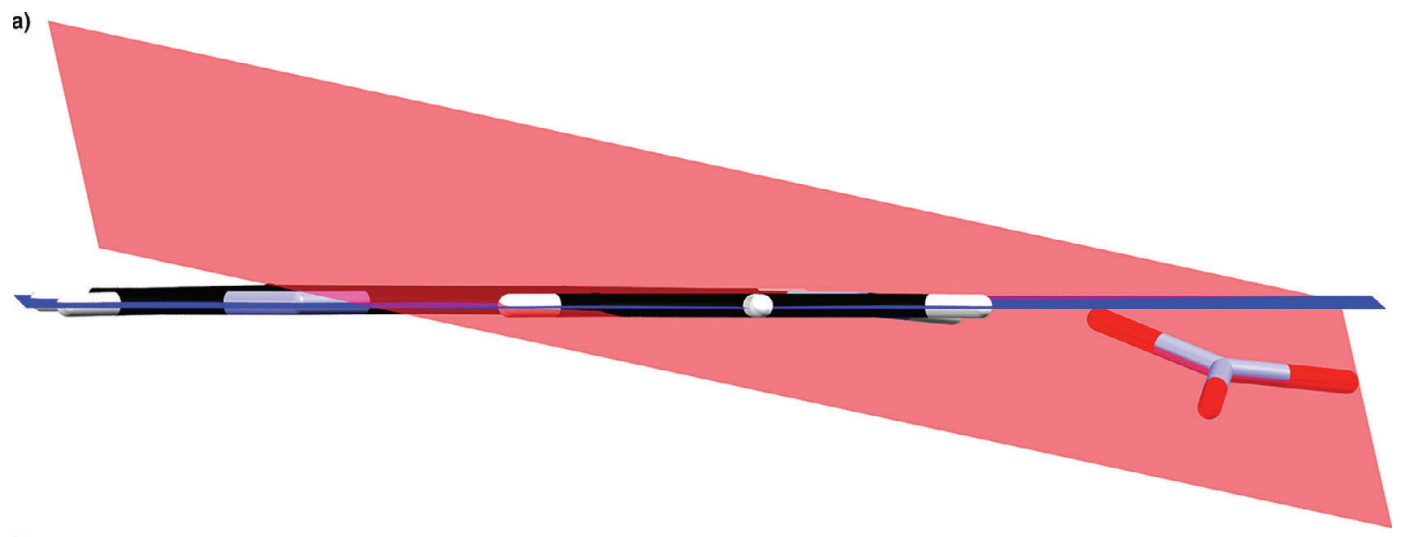

b)

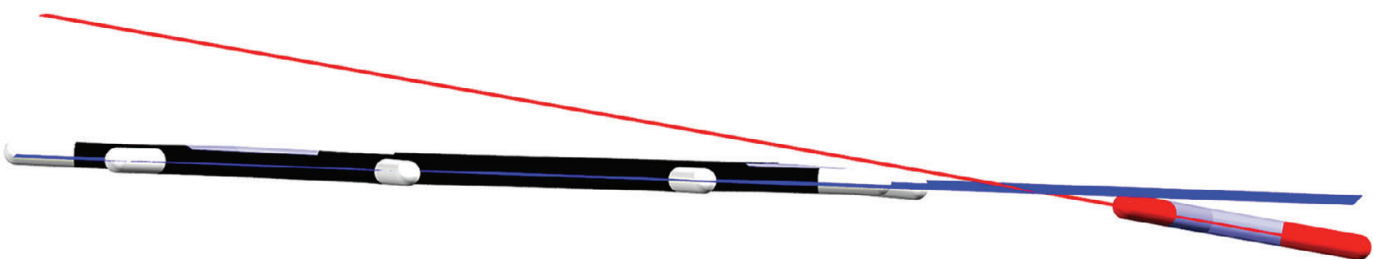

Fig. 3. Angle formed by the intersection of the two planes in $\mathbf{3 a}$ (a) and $\mathbf{3 b}$ (b). The "phenanthrolinium plane" is presented in blue (aligned with the viewing direction), and the "nitrate plane" in red.

Table 4

Minimal inhibitory concentrations (MIC, $\mu \mathrm{M}$ ) against a panel of microorganisms and antiproliferative activity (IC $50, \mu \mathrm{M})$ of copper(II) complexes $\mathbf{1}$ and $\mathbf{2}$ in comparison to CuX 2 salts $\left(\mathrm{X}=\mathrm{NO}_{3}^{-}\right.$and $\left.\mathrm{CF}_{3} \mathrm{SO}_{3}^{-}\right)$.

\begin{tabular}{|c|c|c|c|c|}
\hline Compound & 1 & 2 & $\mathrm{Cu}\left(\mathrm{NO}_{3}\right)_{2} \cdot 3 \mathrm{H}_{2} \mathrm{O}$ & $\mathrm{Cu}\left(\mathrm{CF}_{3} \mathrm{SO}_{3}\right)_{2}$ \\
\hline Staphylococcus aureus & 200 & 400 & $>400$ & $>400$ \\
\hline Listeria monocytogenes & 400 & 400 & $>400$ & $>400$ \\
\hline Pseudomonas aeruginosa & 400 & $>400$ & $>400$ & $>400$ \\
\hline Escherichia coli & 400 & 400 & $>400$ & $>400$ \\
\hline Candida albicans & 400 & $>400$ & $>400$ & $>400$ \\
\hline MRC-5 (human lung fibroblasts) ${ }^{\mathrm{a}}$ & $100 \pm 5$ & $120 \pm 10$ & $300 \pm 10$ & $250 \pm 10$ \\
\hline
\end{tabular}

${ }^{\text {a }} \mathrm{IC}_{50}$ is defined as the concentration inhibiting $50 \%$ of cell growth after $48 \mathrm{~h}$ treatment with the tested compounds.

the antimicrobial activity of copper(II) complexes with antimicrobially active ligands, such as 3,4,7,8-tetramethyl-1,10-phenanthroline and 4,7-diphenyl-1,10-phenanthroline (MIC values are in the range 2.7-90.3 $\mu \mathrm{M}$ ) [48]. No significant difference in the activity against the bacterial strains and $C$. albicans was observed, being in contrast with copper(II) complexes with 2-acetylpyridine- and 2-benzoylpyridine-derived hydrazones, which had slightly better antifungal activitv, although still quite high (MIC values are in
Copper-based complexes have previously been investigated as anticancer agents on the assumption that essential metal ions may be less toxic for normal cells in comparison to cancer cells [23]. Nevertheless, copper can also be toxic due to its redox activity and affinity for binding sites that should be occupied by other metal ions [23]. The investigated copper(II) complexes and starting salts exhibited negative effects on the viability of the healthy human lung fibroblast cell line MRC-5, wherebv complex 1 
ing that some of the observed effects for $\mathbf{1}$ and $\mathbf{2}$ are due to the presence of this ligand $[25,26]$. Recently, $\mathrm{IC}_{50}$ values in the range 24.0-289.0 $\mu \mathrm{M}$ were reported for copper(II) complexes with pyrimidine, pyrazine, quinazoline and phthalazine on the MRC-5 cell line [22], being in accordance with the present findings. On the other hand, copper(II) complexes, which belong to the Casiopeínas ${ }^{\circledR}$ family, $\left[\mathrm{Cu}\left(\mathrm{L}-N, N^{\prime}\right)(\mathrm{X}-N, O)\right] \mathrm{NO}_{3}$ and $\left[\mathrm{Cu}\left(\mathrm{L}-N, N^{\prime}\right)\left(\mathrm{Y}-\mathrm{O}, \mathrm{O}^{\prime}\right)\right]$ $\mathrm{NO}_{3}$, where $\mathrm{L}$ represents 2,2'-bipyridine, 1,10-phenanthroline or their substituted derivatives, $X$ is an essential amino acid or peptide and $\mathrm{Y}$ is either acetylacetonate or salicylaldehydate, showed significant cytotoxicity as a consequence of their ability to interact with DNA [50-56]. The same is true for the mononuclear copper(II) complexes containing $2,2^{\prime}: 6^{\prime}, 2^{\prime \prime}$-terpyridine (terpy) and its $4^{\prime}$-substituted derivatives [57-63].

\section{Conclusions}

We have demonstrated that 1,7- and 4,7-phenanthroline (1,7and 4,7-phen) differ greatly in their ability to coordinate $\mathrm{Cu}(\mathrm{II})$ ion in reactions with $\mathrm{CuX}_{2}$ salts $\left(\mathrm{X}=\mathrm{NO}_{3}^{-}\right.$and $\left.\mathrm{CF}_{3} \mathrm{SO}_{3}^{-}\right)$. Ligand 4,7-phen coordinates monodentately to $\mathrm{Cu}(\mathrm{II})$ ion yielding [Cu $\left.\left(\mathrm{NO}_{3}\right)_{2}(4,7-\mathrm{Hphen})_{2}\right]\left(\mathrm{NO}_{3}\right)_{2}(\mathbf{1})$ and $\left[\mathrm{Cu}\left(\mathrm{CF}_{3} \mathrm{SO}_{3}\right)(4,7-\text { phen })_{2}\left(\mathrm{H}_{2} \mathrm{O}\right)_{2}\right]$ $\mathrm{CF}_{3} \mathrm{SO}_{3}$ (2) complexes, while with 1,7-phen only protonated 1,7phen salts with $\mathrm{NO}_{3}^{-}(\mathbf{3 a} / \mathbf{b})$ and $\mathrm{CF}_{3} \mathrm{SO}_{3}^{-}$(4) counter-ions were obtained. In complex $\mathbf{1}$, obtained from the reaction with $\mathrm{Cu}$ $\left(\mathrm{NO}_{3}\right)_{2}$, both coordinated 4,7-phen ligands have protonated N7 nitrogen atoms. However, in complex $\mathbf{2}$, resulting from the reaction with $\mathrm{Cu}\left(\mathrm{CF}_{3} \mathrm{SO}_{3}\right)_{2}$, no protonation of nitrogen atoms in 4,7-phen ligands occurred. In compounds 1,7-HphenNO $\mathrm{N}_{3}$ (3a/b) and 1,7$\mathrm{HphenCF}_{3} \mathrm{SO}_{3}(4)$, N1 nitrogen atom of 1,7-phen which is not protonated is sterically hindered and consequently not convenient for - $\mathrm{Cu}(\mathrm{II})$ coordination. The antimicrobial and cytotoxic activities of $\mathbf{1}$ and $\mathbf{2}$ against the investigated microbial strains and normal human fibroblast cell line MRC-5, respectively, are moderate, with more pronounced cytotoxic effects.

\section{Acknowledgements}

This research has been financially supported by the Ministry of Education, Science and Technological Development of the Republic of Serbia, under Grants No. 172036 and 173048, and the Swiss National Science Foundation through the SupraMedChem@Balkans.Net SCOPES Institutional Partnership (Project No. IZ74Z0_160515). This research has also received funding from the Serbian Academy of Sciences and Arts under strategic projects programme - grant agreement No. 01-2019-F65 and project of this institution No. F128. AC and KMF thank FriMat (Fribourg Center for Nanomaterials) and the University of Fribourg, Switzerland, for their support.

\section{Appendix A. Supplementary data}

CCDC 1918878-1918882 contains the supplementary crystallographic data for 1-4. These data can be obtained free of charge via http://www.ccdc.cam.ac.uk/conts/retrieving.html, or from the Cambridge Crystallographic Data Centre, 12 Union Road, Cambridge CB2 1EZ, UK; fax: (+44) 1223-336-033; or e-mail: deposit@ccdc.cam.ac.uk. Supplementary data to this article can be found online at https://doi.org/10.1016/j.poly.2019.114112.

\section{References}

[1] E. Alessio (Ed.), Bioinorganic Medicinal Chemistry, Wiley-VCH Verlag GmbH \& Co. KGaA, Wienheim, 2011.

[2] P. deBie, P. Muller, C. Wijmenga, L.W.J. Klomp, J. Med. Genet. 44 (2009) 673.

[3] E. Ladomersky, M.J. Petris, Metallomics 7 (2015) 957.
[4] R.R. Crichton, J.L. Pierre, BioMetals 14 (2001) 99.

[5] E. Madsen, J.D. Gitlin, Annu. Rev. Neurosci. 30 (2007) 317.

[6] P.A. Cobine, F. Pierrel, D.R. Winge, Biochim. Biophys. Acta 1763 (2006) 759.

[7] J.R. Prohaska, Adv. Nutr. 2 (2011) 89.

[8] C.A. Ramsden, P.A. Riley, Bioorg. Med. Chem. 22 (2014) 2388.

[9] Y. Sheng, M. Chattopadhyay, J. Whitelegge, J.S. Valentine, Curr. Top. Med. Chem. 12 (2012) 2560.

[10] J. Finney, H.J. Moon, T. Ronnebaum, M. Lantz, M. Mure, Arch. Biochem. Biophys. 546 (2014) 19.

[11] H.H.A. Dollwet, J.R.J. Sorenson, Trace Elem. Med. 2 (1985) 80.

[12] M. Vincent, P. Hartemann, M. Engels-Deutsch, Int. J. Hyg. Envir. Heal. 219 (2016) 585.

[13] J.V. Prado, A.R. Vidal, T.C. Duran, Rev. Med. Chil. 140 (2012) 1325.

[14] A.L. Casey, D. Adams, T.J. Karpanen, P.A. Lambert, B.D. Cookson, P. Nightingale, L. Miruszenko, R. Shillam, P. Christian, T.S. Elliott, J. Hosp. Infect. 74 (2010) 72.

[15] P. Szymański, T. Frączek, M. Markowicz, E. Mikiciuk-Olasik, Biometals 25 (2012) 1089.

[16] A. Gölcü, M. Dolaz, E.K. Dağcl, KSU J. Sci. Eng. 8 (2005) 4.

[17] M. Shakir, Y. Azim, H.T.N. Chishti, S. Parveen, Spectrochim. Acta A 65 (2006) 490.

[18] B.K. Singh, N. Bhojak, P. Mishra, B.S. Garg, Spectrochim. Acta A 70 (2008) 758.

[19] S. Sreedaran, K.S. Bharathi, A.K. Rahiman, L. Jagadish, V. Kaviyarasan, V. Narayanan, Polyhedron 27 (2008) 2931.

[20] R.S. Kumar, S. Arunachalam, Eur. J. Med. Chem. 44 (2009) 1878.

[21] T. Suksrichavalit, S. Prachayasittikul, C. Nantasenamat, C. Isarankura-NaAyudhya, V. Prachayasittikul, Eur. J. Med. Chem. 44 (2009) 3259.

[22] B.Đ. Glišić, I. Aleksic, P. Comba, H. Wadepohl, T. Ilic-Tomic, J. NikodinovicRunic, M.I. Djuran, RSC Adv. 6 (2016) 86695.

[23] C. Santini, M. Pellei, V. Gandin, M. Porchia, F. Tisato, C. Marzano, Chem. Rev. 114 (2014) 815

[24] N.D. Savić, S. Vojnovic, B.Đ. Glišić, A. Crochet, A. Pavic, G.V. Janjić, M. Pekmezović, I.M. Opsenica, K.M. Fromm, J. Nikodinovic-Runic, M.I. Djuran, Eur. J. Med. Chem. 156 (2018) 760.

[25] A. Pavic, N.D. Savić, B.Đ. Glišíć, A. Crochet, S. Vojnovic, A. Kurutos, D.M. Stanković, K.M. Fromm, J. Nikodinovic-Runic, M.I. Djuran, J. Inorg. Biochem. 195 (2019) 149.

[26] A. Pavic, B.Đ. Glišić, S. Vojnovic, B. Warżajtis, N.D. Savić, M. Antić, S. Radenković, G.V. Janjić, J. Nikodinovic-Runic, U. Rychlewska, M.I. Djuran, J. Inorg. Biochem. 174 (2017) 156.

[27] O.V. Dolomanov, L.J. Bourhis, R.J. Gildea, J.A.K. Howard, H. Puschmann, J. Appl. Cryst. 42 (2009) 339.

[28] G.M. Sheldrick, Acta Crystallogr. A: Found Adv. 71 (2015) 3.

[29] G.M. Sheldrick, Acta Crystallogr. C: Struct. Chem. 71 (2015) 3.

[30] K. Brandenburg, H. Putz, or K. Brandenburg, M. Berndt, DIAMOND, Crystal Impact GbR, Bonn, Germany (1999).

[31] M.B. Hansen, S.E. Nielsen, K. Berg, J. Immunol. Meth. 119 (1989) 203.

[32] S.A. Barnett, A.J. Blake, N.R. Champness, C. Wilson, Dalton Trans. (2003) 2387.

[33] M.-L. Tong, Y.-M. Wu, S.-L. Zheng, X.-M. Chen, T. Yuen, C.-L. Lin, X. Huang, J. Li, New. J. Chem. 25 (2001) 1482.

[34] H. Grove, J. Sletten, M. Julve, F. Lloret, J. Chem. Soc. Dalton Trans. (2000) 515.

[35] H. Grove, J. Sletten, M. Julve, F. Lloret, J. Cano, J. Chem. Soc. Dalton Trans. (2001) 259.

[36] T. Soumahoro, E. Burkholder, W. Oulette, J. Zubieta, Inorg. Chim. Acta 385 (2005) 606.

[37] J. Schottenfeld, R.S. Rarig Jr., J. Zubieta, R.L. LaDuca, Acta Crystallogr. Sect. E Struct. Rep. 63 (2007) 278.

[38] A.W. Addison, T.N. Rao, J. Reedijk, J. van Rijn, G.C. Verschoor, J. Chem. Soc. Dalton Trans. (1984) 1349.

[39] T. Kromp, W.S. Sheldrick, C. Näther, Z. Anorg, Allg. Chem. 629 (2003) 45.

[40] B.J. Hathaway, Comprehensive Coordination Chemistry, Pergamon, Oxford, 1987.

[41] N.S. Drašković, D.D. Radanović, U. Rychlewska, B. Warżajtis, I.M. Stanojević, M. I. Djuran, Polyhedron 43 (2012) 185.

[42] A.S. Potapov, E.A. Nudnova, A.I. Khlebnikov, V.D. Ogorodnikov, T.V. Petrenko, Inorg. Chem. Commun. 53 (2015) 72.

[43] A.B.P. Lever, E. Mantovani, B.S. Ramaswamy, Can. J. Chem. 49 (1971) 1957.

[44] G.A. van Albada, W.J.J. Smeets, A.L. Spek, J. Reedijk, Inorg. Chim. Acta 260 (1997) 151.

[45] J.S. Haynes, S.J. Rettig, J.R. Sams, J. Trotter, R.C. Thompson, Inorg. Chem. 27 (1988) 1237.

[46] R. Prins, P.J.M.W.L. Birker, J.G. Haasnoot, G.C. Verschoor, J. Reedijk, Inorg. Chem. 24 (1985) 4128.

[47] K.N. Lazarou, I. Chadjistamatis, A. Terzis, S.P. Perlepes, C.P. Raptopoulou, Polyhedron 29 (2010) 1870.

[48] N.S. Ng, M.J. Wu, C.E. Jones, J.R. Aldrich-Wright, J. Inorg. Biochem. 162 (2016) 62.

[49] A.A.R. Despaigne, F.B. Da Costa, O.E. Piro, E.E. Castellano, S.R.W. Louro, H. Beraldo, Polyhedron 38 (2012) 285.

[50] J. Serment-Guerrero, P. Cano-Sanchez, E. Reyes-Perez, F. Velazquez-Garcia, M. E. Bravo-Gomez, L. Ruiz-Azuara, Toxicol. In Vitro 25 (2011) 1376.

[51] R. Galindo-Murillo, J.C. García-Ramos, L. Ruiz-Azuara, T.E. Cheatham III, F. Cortés-Guzmán, Nucl. Acids Res. 43 (2015) 5364.

[52] J. Serment-Guerrero, M.E. Bravo-Gomez, E. Lara-Rivera, L. Ruiz-Azuara, J. Inorg. Biochem. 166 (2017) 68. 


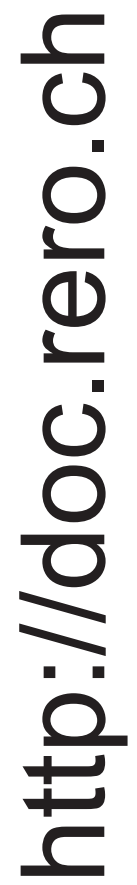

